\title{
THE EFFECT OF ORALLY AND INTRAVENOUSLY ADMINIS- TERED AMINO ACID MIXTURES ON VOLUNTARY FOOD CONSUMPTION IN NORMAL MEN
}

\author{
By CHARLEY J. SMYTH, ANDREW G. LASICHAK, AND STANLEY LEVEY
}

(From the Department of Medicine of Wayne University College of Medicine, Detroit and the Wayne County General Hospital and Infirmary, Eloise, Michigan)

(Received for publication November 26, 1946)

Intravenous and oral protein alimentation using hydrolysates of casein for treatment and prevention of protein deficiency states is receiving increasing recognition. Emphasis has been centered around nitrogen metabolism in such surgical conditions as shock (1), burns (2), blood loss (3, $4)$, wound healing $(5,6,7)$, convalescence $(8,9)$, and postoperative infections $(10,11)$. Numerous investigations (12 to 15 ) have shown that positive nitrogen balance can be maintained for short periods of time in patients receiving intravenous amino acid mixtures as the only source of protein. Another of the major indications for parenteral nitrogen feedings is in patients with debilitating diseases who are unable or unwilling to take adequate food by mouth. In such cases the aim is to supplement the oral nitrogen intake by the use of intravenous protein hydrolysates to provide for the restoration of depleted protein reserves and the daily protein requirements.

During the course of previous investigations in this hospital it was observed that individuals who received intravenous injections of an acid hydrolysate of casein ("Parenamine") failed to eat the normal amount of food at the subsequent meal and many complained of loss of appetite. Reports of the occurrence of nausea, vomiting and anorexia associated with the administration of protein hydrolysates are common $(12,16-23)$. The symptoms of intolerance to these preparations occur most frequently upon rapid injection and constitute one of the disadvantages to their practical use.

Since nausea, vomiting, and anorexia following the infusion of protein digests might result in a decrease in food intake, the advantages offered by intravenous alimentation could thus be offset by a decrease in the consumption of food. The present investigation was undertaken to determine to what extent the administration of solutions of amino acid mixtures would influence the volun- tary food intake in normal individuals. Studies were also carried out on the relationship of the rate of injection of amino acid mixtures to the occurrence of anorexia, nausea, and vomiting.

\section{EXPERIMENTAL}

Eight normal healthy adult males and 1 patient with portal cirrhosis were chosen for this study. They were permitted to be ambulatory except for the time required to complete the infusions. Each subject was offered a standard diet which supplied 3,544 calories. It contained approximately 135 grams of protein, 180 grams fat and 347 grams carbohydrate. Each item of uneaten food was weighed and the amount consumed was calculated as the difference between the weight of food offered and the weight of that returned. The items in the diet were varied to permit some choice. From the weight of the food consumed it was possible to calculate by the use of standard reference tables (24) the total calories and the amount of fat, carbohydrate, and protein consumed each day.

The general plan of the study was to keep the subject on the diet for a few days, then give amino acid preparations either orally or intravenously along with the diet, and note any effect on the food consumption. The days during which added protein was given will be referred to in this report as the experimental period; it lasted from 3 to 7 successive days when the supplemental protein was given orally and from 3 to 6 successive days, usually 3 , when it was given intravenously. The subjects were under continuous observation for from 21 to 35 days. Each individual was studied for at least 2 experimental periods each of which was preceded and followed by control periods of not less than 3 days. Three amino acid preparations were used and they will be designated mixture I, II, and III.1

1 Mixture $I$ is an enzymic digest of casein and pork pancreas and is marketed under the trade name "Amigen," Mead Johnson and Co. Mixture II is an acid hydrolysate of casein to which tryptophane is added. It is marketed as "Parenamine" and was supplied through the courtesy of Frederick Stearns and Co. Mixture III is a synthetic amino acid mixture containing the ten essential amino acids to which glycine is added. The amounts used were suggested by Madden, S. C., and Clay, W. A. (J. Exper. Med., 1945, 82, 65) and referred to by them as mixture "VUJ." It was supplied through the courtesy of Merck and Co. 
The sequence of amino acid mixtures used during the successive experimental periods was varied, as shown in Figures 1A, 1B and 2. Two subjects received only one of the mixtures, 7 subjects received 2 mixtures, and 2 of the subjects also received a 10 per cent glucose solution and physiological saline solution interspersed with the solutions of amino acid mixtures in order to obtain information on the effect that these solutions had on the food consumption (Figure 1B). In 4 subjects the effect of using casein hydrolysates by the oral route was investigated for 5 experimental periods and in these studies only mixture I was used.

The amount of mixtures given on each experimental day was equivalent to 100 grams of protein. ${ }^{2}$ The volume of the solution administered daily was $1,440 \mathrm{ml}$. given in three $480-\mathrm{ml}$. infusions following each meal. Care was taken to arrange infusions so that they would not interfere with meals. The final concentration of amino acid mixture I and II was 8.3 per cent and of mixture III, 8 per cent. The speed of the infusions was purposely varied so that the $480 \mathrm{ml}$. of fluid was delivered in from 60 to 180 minutes. The rate of protein administration, therefore, varied from 13 grams to 40 grams per hour (Table II).

\section{RESULTS}

The results of the influence of oral and intravenous protein supplemental feedings on the amount of food voluntarily consumed during all of the control and experimental periods are summarized on Table I and Figures 1A, 1B, and 2. It can be seen that during the control period when the only source of food was the basal diet, the daily caloric intake remained relatively constant in all subjects. It is also evident that when amino acid Mixture I was given by mouth as the supplemental feeding (Figure 1A) there was little effect on the amount of food eaten. These changes, expressed as calories consumed per day, are interpreted as not being significant. Five subjects received amino acid Mixture I parenterally, and, of these, 4 had little or no depression of the caloric intake. The one patient in whom a depression of appetite occurred (Case No. 2, Figure 1A), had an intake of 67 per cent of the basic control diet. In sharp contrast are the results which occurred in all 7 subjects who received amino acid Mixture II by the intravenous route. There was a constant reduction in the food voluntarily consumed; the average fall was to 61 per cent of the normal con-

\footnotetext{
2 The total nitrogen of each amino acid mixture, based on the data supplied by the manufacturer, was multiplied by 6.25 to give the equivalent of the number of grams of protein.
}

TABLE I

The effect of amino acid preparations on voluntary food consumption

\begin{tabular}{|c|c|c|c|c|c|}
\hline $\begin{array}{l}\text { Pa- } \\
\text { tient } \\
\text { no. }\end{array}$ & Initials & Period of study & $\begin{array}{l}\text { Days } \\
\text { on } \\
\text { study }\end{array}$ & $\begin{array}{c}\text { Aver- } \\
\text { age } \\
\text { total } \\
\text { calaric } \\
\text { intake, } \\
\text { cal. } \\
\text { per } \\
\text { day }\end{array}$ & $\begin{array}{l}\text { Food } \\
\text { con- } \\
\text { sump- } \\
\text { timp, } \\
\text { per } \\
\text { cent } \\
\text { of } \\
\text { control }\end{array}$ \\
\hline 1 & G. S. & $\begin{array}{l}\text { Control } \\
\text { Preparation I orally }\end{array}$ & $\begin{array}{r}16 \\
9\end{array}$ & $\begin{array}{l}3,227 \\
3,313\end{array}$ & 103.0 \\
\hline 2 & S. T. & $\begin{array}{l}\text { Control } \\
\text { Preparation I orally } \\
\text { Preparation I I.V. } \\
\text { Preparation II I.V. } \\
\text { Saline I.V. } \\
10 \text { per cent Glucose } \\
\text { I.V. }\end{array}$ & $\begin{array}{r}34 \\
7 \\
10 \\
3 \\
3 \\
3\end{array}$ & $\begin{array}{r}2,257 \\
2,455 \\
1,523 \\
853 \\
1,948 \\
2,239\end{array}$ & $\begin{array}{r}104.5 \\
67.6 \\
37.8 \\
86.3 \\
99.5\end{array}$ \\
\hline 3 & H. W. & $\begin{array}{l}\text { Control } \\
\text { Preparation I orally } \\
\text { Preparation I I.V. } \\
\text { Preparation II I.V. }\end{array}$ & $\begin{array}{r}17 \\
5 \\
3 \\
3\end{array}$ & $\begin{array}{l}2,783 \\
2,612 \\
2,461 \\
1,693\end{array}$ & $\begin{array}{l}93.6 \\
88.3 \\
60.8\end{array}$ \\
\hline 4 & J. B. & $\begin{array}{l}\text { Control } \\
\text { Preparation I orally } \\
\text { Preparation I I.V. } \\
\text { Preparation II I.V. }\end{array}$ & $\begin{array}{r}22 \\
5 \\
3 \\
3\end{array}$ & $\begin{array}{r}1,807 \\
1,805 \\
1,629 \\
793\end{array}$ & $\begin{array}{l}99.9 \\
90.0 \\
43.0\end{array}$ \\
\hline 5 & W. M. & $\begin{array}{l}\text { Control } \\
\text { Preparation I I.V. } \\
\text { Preparation II I.V. } \\
\text { Saline I.V. } \\
\text { 10 per cent Glucose } \\
\text { I.V. }\end{array}$ & $\begin{array}{r}24 \\
6 \\
4 \\
3 \\
3\end{array}$ & $\begin{array}{l}2,489 \\
2,249 \\
1,493 \\
2,285 \\
2,829\end{array}$ & $\begin{array}{r}90.7 \\
60.2 \\
91.8 \\
111.7\end{array}$ \\
\hline 6 & E. G. & $\begin{array}{l}\text { Control } \\
\text { Preparation II I.V. } \\
\text { Preparation II I.V. }\end{array}$ & $\begin{array}{r}18 \\
4 \\
4\end{array}$ & $\begin{array}{l}2,073 \\
1,600 \\
1,241\end{array}$ & $\begin{array}{l}77.2 \\
59.9\end{array}$ \\
\hline 7 & F. S. & $\begin{array}{l}\text { Control } \\
\text { Preparation II I.V. } \\
\text { Preparation III I.V. }\end{array}$ & $\begin{array}{r}13 \\
3 \\
3\end{array}$ & $\begin{array}{l}3,061 \\
1,907 \\
3,089\end{array}$ & $\begin{array}{r}62.4 \\
101.0\end{array}$ \\
\hline 8 & G.E.F. & $\begin{array}{l}\text { Control } \\
\text { Preparation III I.V. } \\
\text { Preparation II I.V. }\end{array}$ & $\begin{array}{r}18 \\
3 \\
3\end{array}$ & $\begin{array}{l}2,402 \\
2,706 \\
2,081\end{array}$ & $\begin{array}{r}112.2 \\
87.0\end{array}$ \\
\hline 9 & G. C. & $\begin{array}{l}\text { Control } \\
\text { Preparation I I.V. } \\
\text { Preparation III I.V. }\end{array}$ & $\begin{array}{r}23 \\
3 \\
3\end{array}$ & $\begin{array}{l}3,211 \\
3,205 \\
2,711\end{array}$ & $\begin{array}{l}99.8 \\
85.0\end{array}$ \\
\hline
\end{tabular}

sumption with variations ranging from 37.8 per cent to 87 per cent (Table II). This reduction occurred in each of 2 experimental periods in 1 subject (Patient 9, Figure 2) when he was given this preparation. The same results followed the giving of this solution irrespective of whether its use preceded or followed the other 2 mixtures.

Amino acid Mixture III was administered to 3 men (Patients 6, 7, and 8, Figure 2) and no measurable change of food consumption occurred during or following the preparation. Ten per cent glucose and physiological saline infusions were 


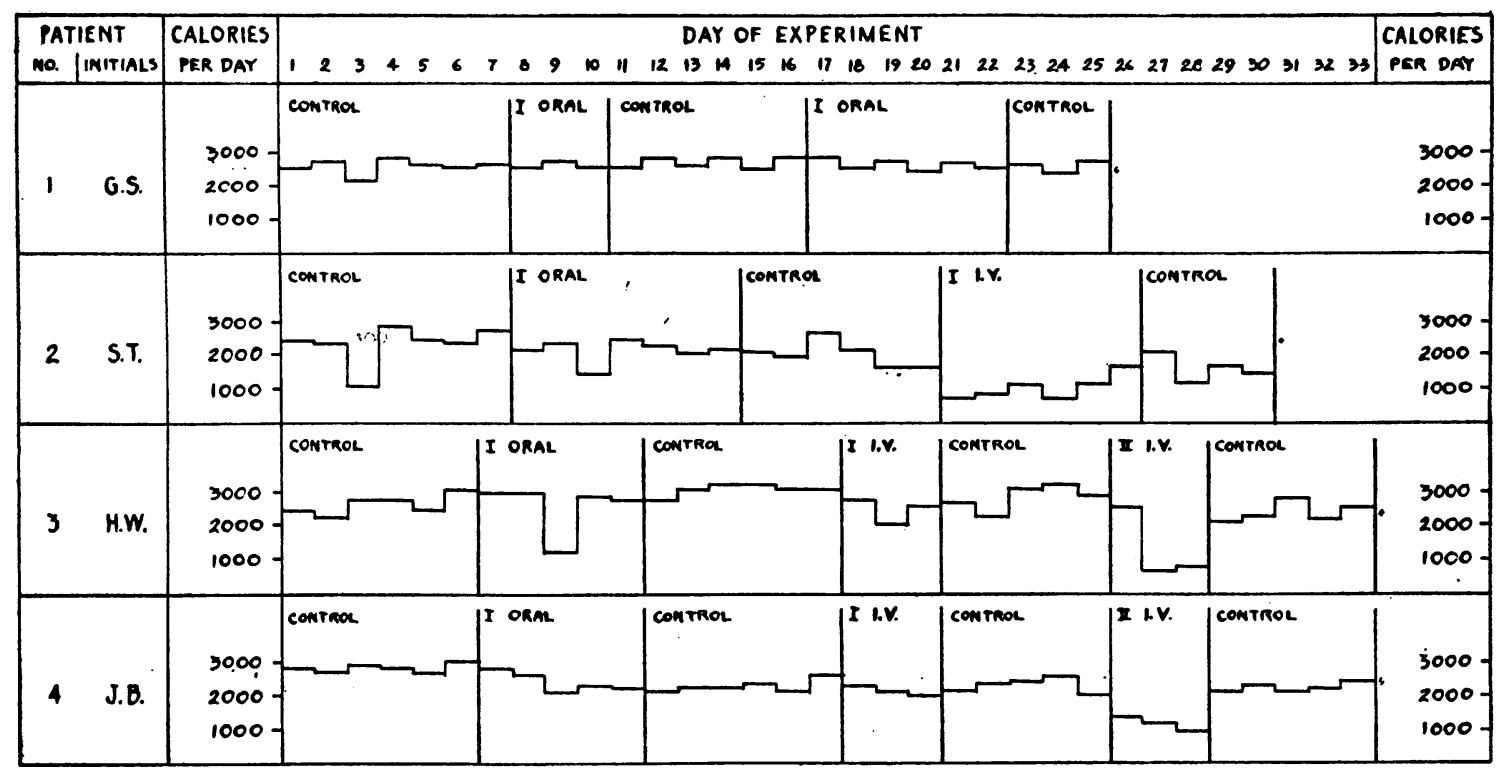

Fig. 1A. Effect of Amino Acid Mixture I Apministered Orally and Intravenously and Amino Acid MixTURE II AdMinistered INTRAVENOUSLY UPON tHE Voluntary FoOd INTAKE

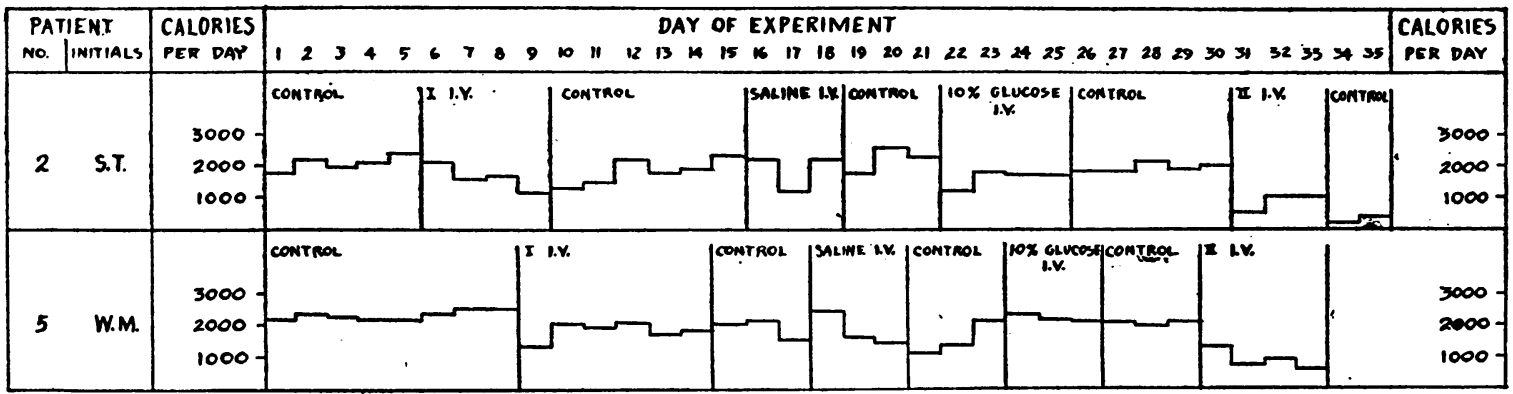

Fig. 1B. Effect of the Intravenous Administration of Amino Actd Mixtures I and II upon the Voluntary Food Intake, Compared with the Intravenous Administration of Physiological Saline and Ten Per Cent Glucose Solution

given to 2 individuals and the results are shown in Figure 1B. These 2 commonly employed solutions produced little effect upon the appetite of these men.

In many experimental periods, notably with patients Nos. 2, 4, 5, 6, and 7, there occurred a stepwise depression of food consumption with each additional day during the infusion of supplementary protein. In some instances this progressive depression extended into the first or even the second day of the following control period. This tendency toward a progressive loss of appetite on the last days of the experimental periods and a lag or overlap into the subsequent control period was particularly notable with the use of Mixture II; it occurred to a lesser degree with Mixture I, and was not observed with Mixture III.

It was observed that an important factor which influenced the consumption of food in these subjects was the reactions occurring with or soon after the subject received the amino acid mixture. In the case of amino acid Mixture III no reactions occurred, but Mixture II produced nausea and vomiting in many of the subjects. Another important complaint of the persons receiving the latter preparation was a burning sensation in the arm while receiving the mixture. The burning extended up the arm along the vein to the axilla and was occasionally followed by thrombophlebitis. The thrombosis and pain in the arms made pro- 


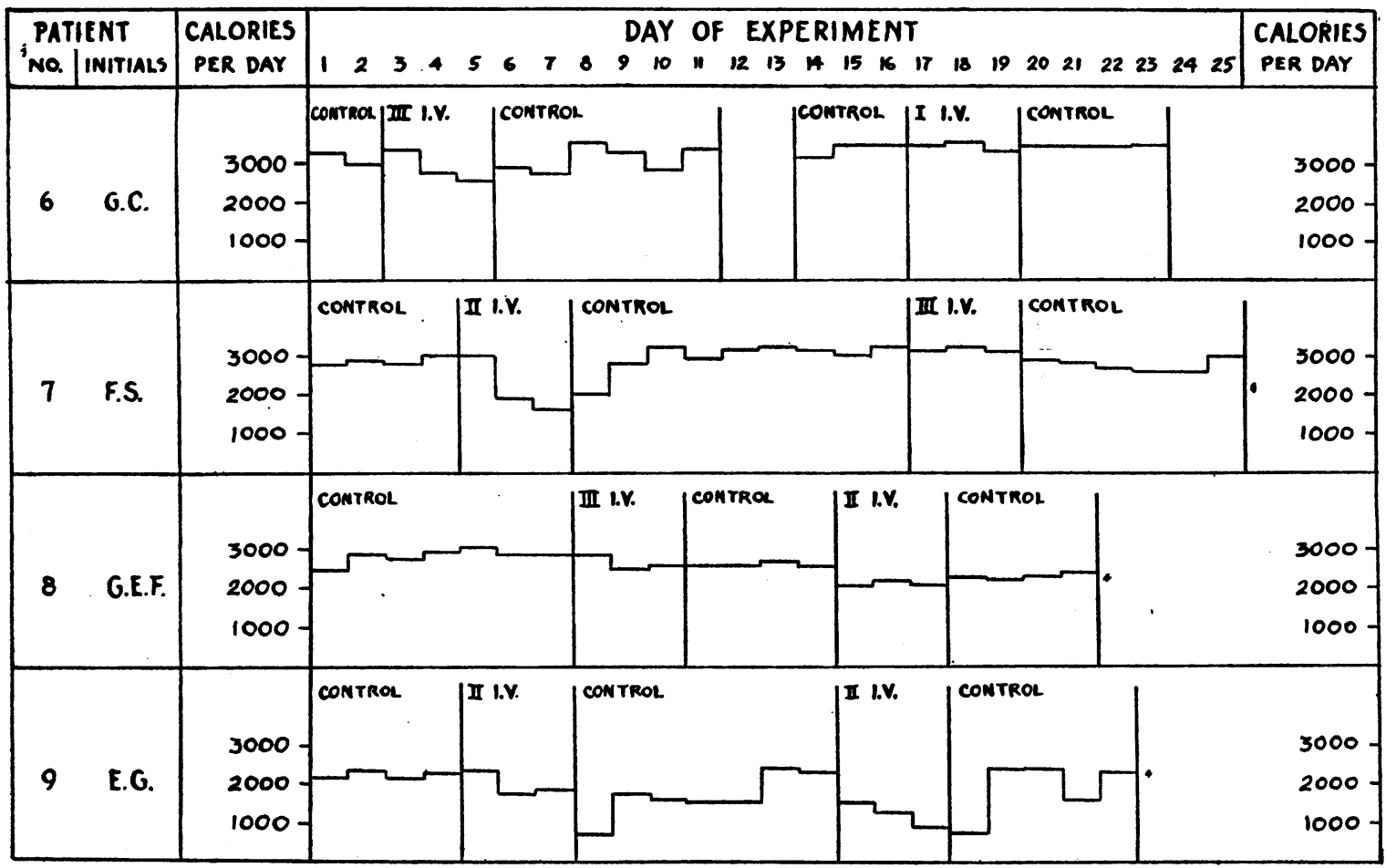

Fig. 2. Effect of Intravenous Administration of Amino Acid Mixtures I, II, and III Upon the VolunTARY FOOD INTAKE

longed administration of this mixture difficult. The depression of appetite as reflected in the decreased food intake was not directly related to the presence or absence of the venous thrombosis because the depression occurred in subjects in whom no vein lesions developed, but the associated pain probably contributed to the poor appetite to some extent. Some of the men complained that after receiving any of these preparations they had an unpleasant taste that was similar to the smell of the casein digest. This peculiar taste was reported by a number of patients and remained for a few days after the administration of the amino acids stopped.

TABLE II

Effects of rates of intravenous administration of amino preparation on voluntary food consumption

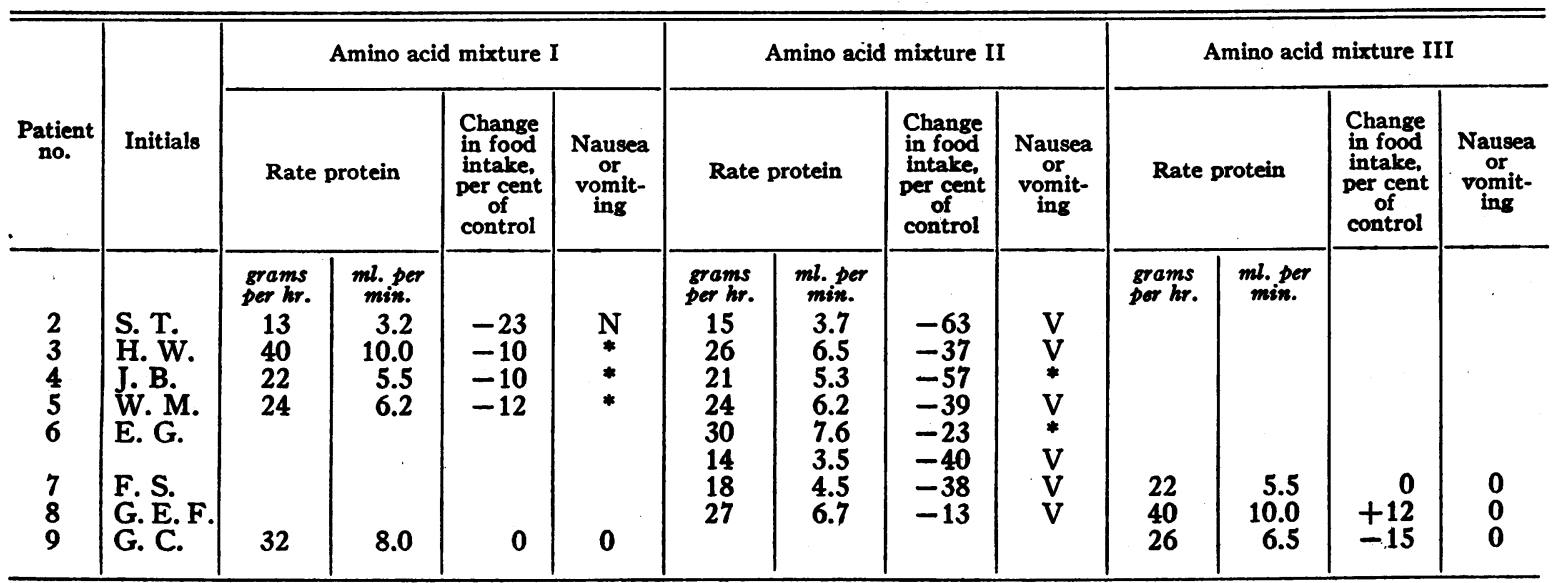

* Information incomplete. 
The results of the studies of the relationship of rate of infusion to the food consumption during intravenous protein feedings are summarized in Table II. Some of the peculiarities involved in the rate of administration of these products can be seen in the data derived from patient H. W. (No. 3 ). Preparation I was given at an average rate equivalent to 40 grams per hour with no ill effects, while Preparation II caused a marked depression in food consumption when given at an average rate of 26 grams of protein per hour. Patient J. B. (No. 4) received both Mixtures I and II at almost identical rates. In this case the drop in calories consumed per day occurred only with the latter mixture. An unusual effect is presented by patient E. G. (No. 9) who received Mixture II on 2 different experimental periods of 3 days each. The rate was 30 grams per hour during the first period and only slight step-wise depression of the total food consumed resulted. At the second experimental period the rate of infusion was approximately $1 / 2$ that of the first period ( 14.5 grams per hour) and on this occasion this same mixture caused a pronounced fall in the amount of food eaten. Mixture III did not cause any change in the appetite as judged by the amount of food consumed, and the rate of its infusion was com- parable to or faster than those used with the other mixtures.

In these cases where there was some reduction in the voluntary intake after the giving of amino acid digests, the question of selective reduction of any one of the major foodstuffs was investigated. The amount of fat, carbohydrate, and protein eaten by each subject was calculated and expressed as the ratio of Protein:Fat: Carbohydrate. Table III is a summary of some of these ratios. There appears to be no constant decrease in consumption of any given class of foodstuffs after amino acid therapy. Variations in the ratios appear, but no trend is evident. In other words, when these individuals cut down on eating they did not tend to avoid selectively the high protein foods and to eat only foods high in carbohydrates or fats.

\section{DISCUSSION}

Co Tui (9) has pointed out that one of the major drawbacks to the clinical use of casein hydrolysates for intravenous protein feedings is the difficulty in giving enough to supply the nitrogen and caloric needs. This is particularly true if it is desired to give large amounts of protein building materials. Elman (25), in presenting a régime for intravenous alimentation of patients suf-

TABLE III

Effect of intravenous amino acid therapy on the ratio of protein: fat: carbohydrate voluntarily consumed Ratio of protein: fat: carbohydrate of standard diet offered $1: 1.32: 2.56$

\begin{tabular}{|c|c|c|c|c|c|c|c|c|c|}
\hline Pt. no. & 1 & 2 & 3 & 4 & 5 & 6 & 7 & 8 & 9 \\
\hline Pt. initials & G. S. & S. T. & H. W. & J. B. & W. M. & E. G. & F. S. & G. E. F. & G. C. \\
\hline - & Fat:CHO* & Fat:CHO & Fat: CHO & Fat: CHO & Fat: CHO & Fat: CHO & Fat: $\mathrm{CHO}$ & Fat: CHO & Fat: CHO \\
\hline $\begin{array}{l}\text { Control } \\
\text { Oral amino acid I } \\
\text { Control } \\
\text { Oral amino acid I } \\
\text { Control } \\
\text { I.V. amino acid I } \\
\text { Control } \\
\text { I.V. amino acid I } \\
\text { Control } \\
\text { I.V. phys. saline } \\
\text { Control } \\
\text { I.V. } 10 \text { per cent } \\
\text { glucose } \\
\text { Control } \\
\text { I.V. amino } \\
\text { acid II } \\
\text { Control } \\
\text { I.V. amino } \\
\text { acid III }\end{array}$ & $\begin{array}{l}1.63: 2.55 \\
1.39: 3.03 \\
1.44: 2.60 \\
1.49: 2.66 \\
1.51: 2.99\end{array}$ & $\begin{array}{l}1.38: 2.50 \\
1.20: 2.45 \\
1.25: 2.58 \\
1.32: 2.66 \\
1.37: 2.50 \\
1.77: 3.70 \\
1.33: 2.49 \\
1.28: 2.28 \\
1.35: 2.42 \\
1.52: 2.95 \\
1.56: 3.20 \\
1.52: 1.76\end{array}$ & $\begin{array}{l}1.77: 3.00 \\
1.54: 2.89 \\
1.54: 2.73 \\
\\
1.56: 3.13 \\
1.61: 2.98 \\
.\end{array}$ & $\begin{array}{l}1.36: 3.06 \\
1.42: 3.22 \\
1.47: 3.22 \\
1.57: 3.90 \\
1.47: 3.22\end{array}$ & $\begin{array}{l}1.30: 1.70 \\
1.34: 1.79 \\
1.64: 1.83 \\
1.40: 1.68 \\
2.60: 2.54\end{array}$ & $\begin{array}{l} \\
1.47: 3.63 \\
1.51: 3.75 \\
1.80: 4.00\end{array}$ & $\begin{array}{l}1.16: 2.80 \\
1.13: 2.40\end{array}$ & $\begin{array}{l}1.39: 3.17 \\
1.38: 3.03\end{array}$ & $\begin{array}{l}1.13: 2.43 \\
1.15: 2.05\end{array}$ \\
\hline
\end{tabular}

* Figures in the table are fat: carbohydrate ratio, protein $=1$. 
fering from severe protein deficiency, advised the giving of both amino acids and glucose. The sum of the volumes of solutions given per 24-hour period amounted to $3,000 \mathrm{ml}$., and the total caloric intake was only 1,200 calories, an amount which usually would not be sufficient for a normal subject to maintain his weight. In this investigation the daily dose of the equivalent of 100 grams of protein was arbitrarily chosen because it was considered an amount adequate to provide the generally recommended allowance of 1 gram of protein per kilogram of body weight and a margin to replace depleted protein reserves.

A practical consideration in giving intravenous protein supplements is to employ a method that will not interfere with the patient's daily food intake. In this study 3 injections were given daily, and the individual infusions were completed in not more than 3 hours. Longer infusions were considered inadvisable from the standpoint of comfort to the patient and because the presence of the needle in the vein was a factor which mechanically interfered with the eating of the regular meals. The rates used with Mixture I and II exceeded those usually recommended. Mixture III was frequently given at rates twice those used with the casein digests. The data regarding the rate of infusion in the present study do not permit any final conclusions.

One of the requirements for an acceptable intravenous preparation is that it must be injectable in adequate amounts without producing nausea, vomiting, or other unpleasant reactions. The relationship of reactions which occurred during or following the infusions to the depression of the appetite is a matter of great practical importance. The one constant finding was that, of the $3 \mathrm{mix}-$ tures used, the greatest impairment in the appetite occurred during those experimental periods when Mixture II was given. However, it is noteworthy that none of the subjects given Mixture III had any side-effects, and in this same group no significant reduction in the consumption of food was observed. When these same patients received Mixture II impairment of the appetite occurred.

At the present time there is no satisfactory explanation for the occurrence of nausea and vomiting. Albanese (26) questioned if these toxic ef- fects were due to unnatural isomers of certain amino acids which cannot be utilized by the human body. Hopps (27) suggests that the presence of some histamine-like substances, peptones or tyramine as agents may explain the frequently observed reactions of flushing, sensation of warmth, and nausea; but he gives no experimental data to support these ideas. Madden and associates (22) have shown that both glutamic and aspartic acids when added to a mixture of pure amino acids will cause violent vomiting in dogs. The effect of these 2 amino acids upon the voluntary food consumption and as a factor causing emesis in humans is being investigated and will be reported in a separate communication. Hoffman, Kozoll, and Osgood (28) have presented evidence that the height of the amino acid nitrogen content of the blood is probably the factor responsible for producing nausea. They found that if the rate is sufficiently rapid to get a blood amino acid nitrogen value of $10 \mathrm{mgm}$. per cent or greater, nausea will result. These studies were carried out using Mixture II. Hecht (21), using Mixture II, has suggested that perhaps the rapidity of the rise of the amino acid blood levels and not the actual levels themselves were responsible for the side effects.

The progressive step-wise reduction in the amount of food voluntarily consumed during the succeeding days of the experimental periods occurred with such regularity, particularly with Mixture II, that it must be considered more than a chance occurrence. The overlap into the subsequent first and second days of the control period and the gradual recovery were the usual findings in these cases. At present there is no explanation for this occurrence.

These studies raise the question as to whether the advantages of giving large doses of amino acid mixtures intravenously are offset by increased urinary nitrogen "wastage" which would be expected to accompany the rapid rates of infusion. In the search for a more acceptable preparation for intravenous use, this important point will require investigation.

\section{SUMMARY}

The effect of the oral and intravenous administration of mixtures of amino acids on the volun- 
tary food consumption in normal human subjects was studied. Three preparations were used: an enzymic hydrolysate of casein (I), an acid hydrolysate of casein (II), and a mixture of the 10 essential amino acids plus glycine (III). The enzymic digest had little effect on the appetite whether it was given orally or intravenously. The acid hydrolysate of casein consistently produced a marked depression in the voluntary food consumption during and following its intravenous administration. The mixture of the essential amino acids had no depressing effect on the appetite. This product was the best tolerated of the 3 tested and could be given at exceedingly rapid rates without any ill effects. When there was reduction in the amount of food eaten, it consisted of a general lack of interest in food rather than a selective rejection of a certain class of foodstuff.

\section{BIBLIOGRAPHY}

1. Elman, R., Acute protein deficiency (Hypoproteinemia) in surgical shock due to severe hemorrhage and in burns, intestinal obstruction and general peritonitis, with special reference to use of plasma and hydrolized protein. J. A. M. A., 1942, 120, 1176.

2. Co Tui, Wright, A. M., Mulholland, J. H., Barcham, I., and Breed, E. S., Nutritional care of cases of extensive burns; with special reference to oral use of amino-acids (Amigen) in 3 cases. Ann. Surg., 1944, 119, 815.

3. Elman, R., and Lischer, C. E., Amino-acids, serum and plasma in replacement therapy of fatal shock due to repeated hemorrhage; experimental study. Ann. Surg., 1943, 118, 225.

4. Nicholl, R. J., Boucher, W. F., and Prince, R. W., Hemorrhagic shock; relative effect of amino acids, Amigen and gelatin in dogs. Surg. Gynec. \& Obst., 1945, 80, 181.

5. Co Tui, Value of protein and its chemical components (amino acids) in surgical repair. Bull. New York Acad. Med., 1945, $21,631$.

6. Thompson, W. D., Ravdin, I. S., and Frank, I. L., Effect of hypoproteinemia on wound disruption. Arch. Surg. 1938, 36, 500.

7. Howard, J. E., Winternitz, J., Parson, W.; Bigham, R. S., and Eisenberg, H., Studies on fracture convalescence; influence of diet on post-traumatic nitrogen deficit exhibited by fracture patients. Bull. Johns Hopkins Hosp., 1944, 75, 209.

8. Howard, J. E., Protein metabolism during convalescence after trauma; recent studies. Arch. Surg., 1945, 50, 166.

9. Co Tui, Some clinical aspects of protein nutrition. J. Amer. Dietet. A., 1946, 22, 97.
10. Cannon, P. R., Protein metabolism and resistance to infection. J. Michigan M. Soc., 1944, 43, 323.

11. Cannon, P. R., Importance of proteins in resistance to infection. J. A. M. A., 1945, 128, 360.

12. Madden, S. C., Bassett, S. H., Remington, J. H., Martin, F. J. C., Woods, R. R., and Shull, F. W., Amino acids in therapy of disease; parenteral and oral administrations compared. Surg. Gynec. \& Obst., 1946, 82, 131.

13. Bassett, S. H., Woods, R. R., Shull, F. W., and Madden, S. C., Parenterally administered amino acids as source of protein in man. New England J. Med., 1944, 230, 106.

14. Elman, R., Charnas, R., and Davey, H. W., Ceiling of utilization of nitrogen. Arch. Surg., 1943, 47, 216.

15. Brunschwig, A., and Corbin, N., Clinical study of relative efficiency for nitrogen metabolism of casein administered intravenously and protein ingested by mouth. Surgery, 1943, 14, 898.

16. Davis, $H$. H., Amino acids intravenously in surgical patients. Nebraska M. J., 1945, 30, 51.

17. Hartmann, A. F., Parenteral administration of amino acids. J. Pediat., 1945, 26, 193.

18. Elman, R., Parenteral fluids and food in gastrointestinal disease. Bull. New York Acad. Med., 1944, $20,220$.

19. Brunschwig, A., Clark, D. E., and Corbin, N., Intravenous injection of casein digest (amino acids) in maintenance of nutrition; consideration of medico-military aspects. Mil. Surgeon, 1943, 92, 413.

20. Landesman, R., and Weinstein, V. A., Intravenous use of amino acids for nutritional purposes in surgical patient. Surg. Gynec. \& Obst., 1942, 75, 300.

21. Hecht, H. H., Reactions to intravenously administered amino acids (casein hydrolysates). Am. J. M. Sc., 1946, 212, 35.

22. Madden, S. C., Woods, R. R., Shull, F. W., Remington, J. H., and Whipple, G. H., Tolerance to amino acid mixtures and casein digests given intravenously; glutamic acid responsible for reactions. J. Exper. Med., 1945, 81, 439.

23. Unna, K., and Howe, E. E., Toxic effects of glutamic and aspartic acid. Fed. Proc. 1945, 4, 138.

24. Bowes, A. P., and Church, C. F., Food values of portions commonly used. Philadelphia Child Health Society, Philadelphia, Penn. 1942.

25. Elman, R., The practical use of amino acids in protein nutrition. J. A. M. A., 1945, 128, 659.

26. Albanese, A. A., The utilization of d-amino acids by man; tryptophane, methionine and phenylalanine. Bull. Johns Hopkins Hosp., 1944, 75, 175.

27. Hopps, H. C., and Campbell, J. A., Immunologic and toxic properties of casein digest is prepared for parenteral administration. J. Lab. \& Clin. Med., 1943, 28, 1203.

28. Hoffman, W. S., Kozoll, D. D., and Osgood, B., Blood chemical changes following intravenous administration of a casein hydrolysate to human subjects. Proc. Soc. Exper. Biol. \& Med., 1946, 61, 137. 